\title{
Judta i Snydera wiek dwudziesty
}

Thinking the twentieth century

Tony Judt, Timothy Snyder

Nowy Jork 2012, ss. 432.

Tstąc stnieją książki, których recenzje wypada zacząć od kilku słów będących świadectwem pokory. Pewien znany magazyn literacki poprosił raz Dorotę Masłowską o napisanie paru zdań, które przybliżyłyby polskiemu czytelnikowi twórczość rumuńsko-niemieckiej pisarki Herty Müller, laureatki Literackiej Nagrody Nobla z 2009 r. Autorka Pawia Królowej przyznała się wtedy do swojej bezradności: „To jest proza, o której trudno napisać, bo wszystko jest ciągle za mało. Ja nie potrafię o tym napisać wyczerpująco, ale wiem na pewno, że to jest niesamowite, jest to jedna z najniesamowitszych książek, jakie w ogóle czytałam". W przypadku Thinking the twentieth century (Myśląc dwudziesty wiek) mam bardzo podobne odczucia.

Wszystko w tej pracy wydaje się być genialne i jednocześnie wszystko jest tutaj na swoim miejscu, każde zdanie jest potrzebne, każda opinia intrygująca, każda metafora trafiona. Jakakolwiek próba przekształcenia czy też ingerencji w to, co na tych ponad 400 stronach przekazali nam Tony Judt i Timothy Snyder musi liczyć się z tym, że okaże się tylko bladą kopią, niezręczną parafrazą czy też przepisaniem ich wiersza pośledniej jakości prozą. Tak samo jak to bywa z wielkimi książkami o ludziach wielkich, które, jak słusznie zauważył Zygmunt Bauman, zliczyć można na palcach jednej ręki, równie ciężko trafić na wybitną recenzję wybitnej książki.

A jednak kolejne recenzje powstają i następne debaty o tej książce się toczą i nie ma w tym nic dziwnego, bo lektura rozmowy T. Judta i T. Snydera rozbudza wielki głód rozmowy dalszej, kreuje domagającą się natychmiastowego zaspokojenia potrzebę kontaktu z innymi oraz spierania się i dyskutowania o tym, co się właśnie przeczytało. Bo T. Judt i T. Snyder mają ten rzadki dar, że choć potrafią czytelnika

\footnotetext{
${ }^{1}$ H. Müller, Głód i jedwab, Wołowiec 2008, s. 203.
} 
zachwycić, to jednak go nie onieśmielają. Ich książka nie jest zbiorem arbitralnie dostarczonych prawd, autorzy nie wykładają niczego ex cathedra, ani nie mówią do nas z ambon swojej nieomylności; raczej wydają się nas zachęcać, abyśmy się ich dyskusji uważnie przysłuchiwali, a także dzielili swoimi spostrzeżeniami. Pewnie właśnie dlatego raz przeczytana nigdy ostatecznie nie zostaje odłożona na półkę, powraca się do niej oraz ma się ochotę opowiedzieć o niej innym i podzielić się swoimi refleksjami.

Interesująca jest już sama historia powstania dzieła. Amerykański historyk T. Snyder zaproponował T. Judtowi wspólne przygotowanie tej pracy w grudniu 2008 r. Trzy miesiące wcześniej u T. Judta zdiagnozowano stwardnienie zanikowe boczne, nazywane też często chorobą Lou Gehriga - rzadkim, nieuleczalnym schorzeniem neuronu ruchowego, które wywołuje stopniowy paraliż całego ciała, a na końcu śmierć chorego. T. Judt był wtedy u szczytu swojej kariery zawodowej: trzy lata wcześniej wydał będące owocem kilkunastu lat pracy, podróż i lektur, monumentalne Powojnie. Historię Europy od 1945 roku, powitane oklaskami krytyki i głosami uznania czytelników. Po przeprowadzce do Ameryki, okrzyczany przez wielu „najżywszym umysłem Nowego Jorku” ${ }^{2}$, był stałym gościem na łamach „The New York Review of Books” i „The New Republic”, gdzie niemal każdy jego esej wywoływał burzę3. W ramach New York University, gdzie pracował, był szefem założonego przez siebie Instytutu Remarque'a, będącego płaszczyzną dialogu między Ameryką i Europą oraz miejscem intensywnych, multidyscyplinarnych studiów nad starym kontynentem. Diagnoza, którą T. Judt usłyszał od lekarzy, podała w wątpliwość możliwość skutecznej realizacji dalszych planów zawodowych, w tym tego najważniejszego: napisania książki będącej intelektualną historią XX w.

O pracy, która przedstawiałaby najważniejsze prądy intelektualne i dzieje XX-wiecznej myśli politycznej i społecznej, jej historyczno-kulturowe konteksty, a także portrety jej najwybitniejszych repre-

${ }^{2}$ Z. Bauman, Zygmunt Bauman o Tonym Judcie, „Gazeta Wyborcza”, http://wyborcza.pl/1,75475,10072009,Zygmunt_Bauman_o_Tonym_Judcie.html, 02.01.2013 r.

3 T. Judt skutecznie wcielał w życie maksymę polskiego intelektualisty przełomu XIX i XX w. Stanisława Brzozowskiego, który mawiał, że każda stronica tekstu powinna mu zrobić w świecie literackim jednego przynajmniej wroga. Z drobną tylko przesadą można powiedzieć, że trudno znaleźć esej pióra T. Judta, którym ktoś nie byłby oburzony i który nie wywołałby listów do redakcji; najczęściej autorstwa tych, którym nie przypadła do gustu napisana przez T. Judta recenzja ich książki. To również powód, dla którego jego styl nieustannie określany był jako polemiczny. To zresztą epitet, który przylgnął do T. Judta na trwałe, wydaje się, iż nie bez satysfakcji scharakteryzowanego. 
zentantów, historyk myślał od dawna. Do pewnego stopnia - jak sam przyznawał - istniała ona już w jego głowie ${ }^{4}$. Postęp choroby mógł jednak sprawić, że jej ostateczne ukończenie: szkic tekstu, szukanie materiałów źródłowych, niezbędne lektury i w końcu napisanie całości okazałoby się być ponad jego siły. I właśnie wtedy do T. Judta przyszedł T. Snyder, który wiedział zarówno o pomyśle na książkę, jak i o chorobie, która już wkrótce może zniweczyć szanse jego realizacji.

Profesor Yale University, dzielący z T. Judtem pośród wielu rzeczy profesję, predylekcję wobec regionu Europy Środkowo-Wschodniej oraz formację intelektualną angielskiego Oxbridge, zaproponował serię długich i nagrywanych konwersacji, w których obaj przedyskutują miniony wiek. Początkowo sceptycznie nastawiony do pomysłu T. Judt dał się przekonać i przystał na propozycję T. Snydera. I tak, między zimą a latem 2009 r. w każdy czwartek T. Snyder przyjeżdżał pociągiem z New Haven do Nowego Jorku, aby być w domu T. Judta na 11 rano na umówioną rozmowę. Ich zapis tworzy Thinking the twentieth century.

O czym jest ta książka? O neoklasycznej ekonomii, nazizmie i faszyzmie, syjonizmie, liberalizmie, marksizmie i komunizmie, socjaldemokracji i państwie dobrobytu, wreszcie rewolucji neoliberalnej i globalizacji; słowem o wszystkim tym, co T. Judt nazwał raz filarami XX-wiecznego świata politycznego ${ }^{5}$. O mocy idei w czasach, w których idee miały swoje konsekwencje jak nigdy wcześniej oraz o szczególnej roli i odpowiedzialności intelektualistów. A także trochę o życiu osobistym samego T. Judta.

Największa siła książki jest zarazem pułapką zastawioną na recenzentów, w którą wpadają, podejmując próby streszczenia dyskusji autorów, czy choćby zarysowania głównych wątków ich rozmowy. Choć T. Snydera i T. Judta dzieli zarówno różnica geograficzna, jak i pokoleniowa (T. Judt wychowywał się w powojennym Londynie Clementa Atlee, T. Snyder w Ohio w północno wschodniej Ameryce czasów Ronalda Reagana), to razem tworzą coś, co można by nazwać perfect match (idealnym dopasowaniem). Sam T. Snyder stwierdził, że w toku rozmowy okazało się, że jego mentalna biblioteka znacząco pokrywa się z tą T. Judta ${ }^{6}$. I rzeczywiście; już po kilkudziesięciu stronach czytelnik przekonuje się, że T. Snyder czytał niemal wszystko to, co T. Judt

${ }^{4}$ T. Judt, Thinking the twentieth century, New York 2012, s. 389.

5 Idem, Reappraisals. Reflections on the forgotten twentieth century, London 2008, s. 3 .

${ }^{6}$ Idem, Thinking ..., s. xii. 
i na odwrót; jeśli jeden w swojej wypowiedzi nawiązuje do jakiejś książki bądź autora, drugi zaraz wtrąci się ze swoją opinią na ten temat, bo też to zna. Wiedza i temperament dyskutantów rozsadzają pierwotnie nakreślone ramy tematyczne rozmowy; ich dialog aż kipi od literackich referencji, politycznych odniesień, przeskoków w czasie i przestrzeni, a wszystko to razem czyni ich wspólną książkę tak gęstą, że każde jej gazetowe streszczenie wydaje się nie przystawać, a nawet uchybiać całości. A jednocześnie T. Judt i T. Snyder chyba ani razu nie mówią banału. Jak trafnie zauważył Neal Ascherson w tekście w „The Guardian”, ta dwójka wybitnych historyków „ma coś frapującego i oryginalnego do powiedzenia niemal na każdy poruszony temat"7. To sprawia, że ta książka jest pasjonująca nie tylko w jej głównym wątku, tam gdzie T. Judt i T. Snyder dyskutują największe idee i projekty polityczne XX w., ale również, a czasami nawet bardziej, na jej marginesach, tam gdzie rozmówcy robią dygresje, pozwalają sobie na złośliwość pod czyimś adresem albo dają upust swej wolności skojarzeń.

Jedną z takich drobnych obserwacji, ujmujących swoją prostotą i pięknem jednocześnie, jest ta, którą podzielił się T. Snyder na temat butelkowanej wody. Woda - mówił - jest bardzo ważna; musimy ją pić, aby przeżyć; kąpiemy się w niej; potrzebujemy jej, aby być czyści, jednak nie ma żadnego powodu, aby umieszczać ją w butelkach. Dawniej dobrym obyczajem było udostępnianie szklanki wody nieznajomemu, który zapukał do drzwi naszego domu, aby spragniony mógł się napić. Dziś wlewamy ją w butelki i sprzedajemy za pieniądze, dewaluując dobro publiczne, które już dawno udało nam się osiągnąć - czystą wodę w kranie. Jak bardzo można jeszcze zdegenerować cywilizację, udając, że to jest postęp? - pytał T. Snyder.

Takich intrygujących spostrzeżeń jest w tej książce pełno; wiele z nich skłania do refleksji, niektóre wywołują nostalgię, niemało powoduje uśmiech na twarzy. Zabawny jest moment, gdy rozmówcy wdają się w rozważania o charakterze autotematycznym, zastanawiając się, po co właściwie spotykają się co tydzień i nagrywają swoje konwersacje, a także co się stanie z ich książką po jej opublikowaniu. T. Judt upiera się następnie przy tezie, że choć istnieje globalna przestrzeń wymiany intelektualnej i globalny obieg książek, to nie ma niestety globalnego audytorium, a tym samym nie istnieje nic takiego jak glo-

${ }^{7}$ N. Ascherson, Thinking the twentieth century - review, „The Guardian”, http:// www.guardian.co.uk/books/2012/feb/o2/tony-judt-thinking-twentieth-century-review, 02.01.2013 r. 
balny intelektualista: „Slavoj Žižek po prostu nie istnieje”8 - oznajmia T. Judt.

Co może wydawać się zaskakujące, jak na rozmowę ze szczerym socjaldemokratą i człowiekiem lewicy, jakim całe życie był T. Judt, padają tu zdania, których nie powstydziliby się najwięksi konserwatyści. Ów konserwatywny rys widać tam, gdzie T. Judt i T. Snyder dyskutują o metodologii nauk historycznych i cechach dobrej książki historycznej. Krytykują sam pomysł i popularność, jaką na zachodnich uniwersytetach cieszą się tzw. cultural studies (studia kulturowe), w tym znane także i u nas gender studies, przypominają projekt socjaldemokratyczny i powojenne państwo dobrobytu oraz mówią o wspomnianej już niesłabnącej dominacji „rejestru narodowego" w przetwarzaniu informacji i tematów, będących przedmiotem debaty publicznej.

We fragmencie rozmowy, gdzie dyskutowane jest dobre rzemiosło historyczne, T. Judt i T. Snyder opowiadają się po stronie całościowych narracji i wielkich syntez historycznych, łączących ze sobą myśl polityczną, ekonomię oraz kontekst społeczno-kulturowy. Kryterium oceny jakości takiej książki jest proste: inteligentny czytelnik niespecjalista winien uznać ją za prawdziwą. Irena Grudzińska-Gross sugeruje, że chodzi tu o wersję historii uprawianą przez „szkołę Oxbridge”, czyli autorów takich jak Eric Hobsbawm, Norman Davis, Timothy Garton Ash, Paul Kennedy, Mark Mazower czy Niall Ferguson. Książki tych historyków łączy ogromny materiał źródłowy, na jakim są oparte, dostępny i zrozumiały język, ukryta przed czytelnikiem metodologia, energiczna, lecz linearna narracja oraz stylistyczny konserwatyzm ${ }^{9}$ Jakkolwiek niepozbawiona wad i niedoskonałości, tylko taka historia - zdają się mówić T. Judt i T. Snyder - podtrzymuje naród jako wspólnotę wyobrażoną oraz jest w stanie wyposażyć daną zbiorowość w przeszłe referencje współczesnych doświadczeń, a tym samym nadać teraźniejszości znaczenie przez odniesienie do przeszłości ${ }^{10}$.

8 T. Judt, Thinking..., op. cit., s. 298.

9 I. Grudzińska-Gross, Cicha desperacja, „Przegląd Polityczny” 2012, nr 115/116, s. 85. Dodać należy, że choć wymienionych autorów faktycznie łączy pewna wspólnota formy, o której pisze I. Grudzińska-Gross, to na poziomie treści przekazu równie wiele ich dzieli. Najbardziej jaskrawą opozycją byłoby tu zestawienie Nialla Fergusona i Erica Hobsbawma. Tę dwójkę oprócz formy łączy chyba tylko jedno: obaj uważają zmianę paradygmatu ekonomicznego za fundamentalną dla ukształtowania ery nowoczesnej. Różni ich jednak zupełnie punkt widzenia, jaki przyjmują, patrząc na procesy historyczne.

${ }^{10}$ Słuszne zastrzeżenia do takiej wersji historii zgłosiła I. Grudzińska-Gross pisząc, 
Jednym z takich niesłusznie zapomnianych punktów odniesienia dla wielu współczesnych dylematów powinno być powojenne państwo dobrobytu (welfare state). Rozdział książki poświęcony socjaldemokracji - zatytułowany Banalność dobra - jest jednym z najbardziej przejmujących w całej pracy. Pobrzmiewa w nim elegijny ton oraz nuta konserwatywnej nostalgii. Już w Źle ma się kraj T. Judt sugerował, że tak naprawdę jedyną prawdziwie konserwatywną spośród dzisiejszych opcji politycznych są socjaldemokraci, gdyż próbują bronić świata, który zanika na naszych oczach, podmywany przez płynną nowoczesność i logiki neoliberalnej globalizacji ${ }^{11}$. Należy pamiętać, że w Thinking... T. Judt i T. Snyder przypominają państwo dobrobytu czasów stabilnego trójkąta instytucjonalnego, złożonego z wielkich i liczebnych partii politycznych, organizacji pracodawców prywatnych i silnych związków zawodowych, który umożliwiał skuteczną socjaldemokratyczną reprezentację na poziomie sceny politycznej. Ówczesna polityka, prowadzona $\mathrm{w}$ ramach pojedynczego organizmu państwowego, miała realną zdolność do nadawania kierunku mocy ${ }^{12}$ oraz do czy-

że ten „typ konserwatywno-liberalnej i narodowej historii niesie ze sobą wielkie ryzyko” i „nie wydaje się być najskuteczniejszym sposobem zmierzenia się z rzeczywistością”. I. Grudzińska-Gross, która sama jest historykiem idei, przypomina, że „różne są historie, różne ich podmioty i różni odbiorcy” i pyta, dlaczego to właśnie naród „ma być tak radykalnie uprzywilejowanym podmiotem historii”. Zob. I. Grudzińska-Gross, op. cit., s. 184. Wydaje się jednak, że autorka zbyt łatwo kreśli portret T. Judta jako jednoznacznego zwolennika konserwatywno-liberalnej wersji historii. Nie jest to zgodne ani z pisarstwem historycznym samego T. Judta, ani z tym, co sam pisał o książkach innych autorów. Kto jak kto, ale I. Grudzińska-Gross - prywatnie dobra znajoma T. Judta, wie doskonale, że był on wielkim zwolennikiem książek jej męża Jana Tomasza Grossa, o których wiele można powiedzieć, ale nie to, że oparte są na konserwatywnej metodologii historycznej, albo poruszane konserwatywną narracją. Wystarczy przypomnieć słynny apel J. T. Grossa o „nowe podejście do źródeł” przy zbieraniu relacji od świadków Zagłady, a także to, że w swoich esejach historycznych często korzysta on z instrumentarium pokrewnych wobec historii dyscyplin, takich jak socjologia czy antropologia historyczna, chociażby kategorii „gęstego opisu”. Nie był też T. Judt osobą zamkniętą na nowe podejścia metodologiczne funkcjonujące w badaniach historycznych, chociażby związane z wprowadzoną przez Pierre’a Norę kategorią „miejsc pamięci”. Widać to w mieszczonym w tomie Reappraisals tekście À la recherche du temps perdu: France and Its Pasts, gdzie T. Judt niezwykle pozytywnie recenzuje monumentalne siedmiotomowe dzieło Pierre'a Nory Les lieux de memoire. Zob. T. Judt, Reappraisals..., London 2008, s. 196.

${ }^{11}$ T. Judt, Źle ma się kraj, Wołowiec 2011, s. 194.

12 Z. Bauman, Świat po pigułce, „Polityka”, http://www.polityka.pl/kraj/ rozmowyzakowskiego/1511368,1,z-prof-zygmuntem-baumanem-socjologiem.read, $02.01 .2013 \mathrm{r}$. 
nienia różnicy ${ }^{13}$.

Formy gospodarcze epoki kapitalizmu informacyjnego wymuszają inne formy społeczne, zmienia się mechanizm zawiązywania więzi grupowych i uświadamiania wspólnoty interesów, inne są cele (choć uniwersalna gramatyka) dzisiejszych ruchów protestu; co więcej, świat już piąty rok walczy ze strukturalnym i wielowymiarowym kryzysem, który błyskawicznie zmienia parametry społeczno-ekonomiczne dotychczasowej rzeczywistości oraz skutkuje pączkowaniem jeszcze nierozpoznanych nowych kultur i instytucji ${ }^{14}$. Wszystko to sprawia, że rozwiązania i instrumenty polityczne organizujące rzeczywistość w połowie XX w. nie są wystarczającym remedium na obecne problemy. T. Judt i T. Snyder jednak doskonale to wiedzą i - wbrew temu, co przypisuje im wielu interpretatorów tej książki - wcale nie proponują bezkrytycznego powrotu do starych recept ${ }^{15}$. Przypominają tylko o perenializmie najważniejszych dylematów i pytań; o tym, że powojenna socjaldemokracja próbowała się mierzyć - i czyniła to niezwykle skutecznie - z istotnymi problemami; podczas gdy my na końcu historii udawaliśmy, że one w ogóle nie istnieją.

W świecie, którego najprawdziwszą namiętnością jest „radość pozbywania się rzeczy, kończenia z nimi, porzucania ich i wyrzucania na śmietnik"16 książka T. Judta i T. Snydera jest być może najradykalniejszym, jaki można sobie wyobrazić, manifestem przeciwko tej namiętności. Także dlatego jest to książka wybitna.

\section{NotA O AUTORZE}

Rafał Szymanowski [rafal.szymanowski@gazeta.pl] - student II roku studiów II stopnia na kierunku Stosunki Międzynarodowe na Wydziale Nauk Politycznych i Dziennikarstwa UAM. Członek Koła

${ }^{13}$ J. Staniszkis, O władzy i bezsilności, Kraków 2006; za: E. Bendyk, Antymatrix, http://bendyk.blog.polityka.pl/2006/o9/20/jadwiga-staniszkis-o-wladzy-i-bezsilnosci/, 02.01.2013 r.

${ }^{14}$ M. Castells, J. Caraça, G. Cardoso, Aftermath. The Cultures of the Economic Crisis, Oxford 2012, s. 13.

${ }^{15}$ Choć wydaje się, że w pewnych obszarach rzeczywistości nic nie byłoby nam równie pilnie potrzebne, jak właśnie powrót do starych i sprawdzonych recept. O tym jak wiele $\mathrm{z}$ fundamentalnego dorobku XX-wiecznej makroekonomii zginęło w mrokach niepamięci oraz jak fatalne są tego następstwa dla polityki zarządzenia obecnym kryzysem gospodarczym i łagodzenia jego skutków zob. P. Krugman, End this depression now!, New York 2012.

${ }^{16}$ Z. Bauman, 44 listy ze świata płynnej nowoczesności, Kraków 2011, s. 150. 
Naukowego Studiów Genderowych. Interesuje się ekonomią polityczną, procesami globalizacji, problematyką zmian cywilizacyjnych oraz obecnym światowym kryzysem gospodarczym, a także przyszłością socjaldemokracji oraz państwa dobrobytu. Pisze pracę magisterską poświęconą myśli politycznej Tony’ego Judta. 